10. Haider BA, Baras AS, McCall MN, Hertel JA, Cornish TC, Halushka MK. A critical evaluation of microRNA biomarkers in non-neoplastic disease. PLoS ONE 2014;9:e89565.

${ }^{1}$ Author disclosures: K. W. Witwer, no conflicts of interest.

*To whom correspondence should be addressed. E-mail: kwitwer1@jhmi.edu.

doi:10.3945/jn.114.202523

\section{Reply to Witwer ${ }^{1,2}$}

Dear Editor,

We appreciate Witwer's interest in our work on the bioavailability of milk microRNAs (miRNAs) in humans and mice $(1,2)$. Witwer raises concerns that the postprandial increases in plasma miRNA (miR)-29b and miR-200c concentrations after a milk meal might be due to milk-dependent endogenous miRNA synthesis, as opposed to absorption from milk (1). Although it is certainly a possibility that dietary compounds alter the expression of genes coding for miRNAs (3), we maintain our original position that mammals absorb bovine miRNAs from milk. This position is based on the following lines of evidence. First, milk miRNAs are encapsulated in exosomes (4-6). There is consensus that human cells transport human exosomes by using carrier-mediated processes and phagocytosis (7-10). Recently, we observed for the first time that human intestinal cells also transport milk exosomes through a process that follows saturation kinetics, is inhibited at low temperatures $\left(4^{\circ} \mathrm{C}\right)$, and is inhibited when surface proteins are removed from exosomes or intestinal cells by proteinase K treatment (T. Wolf, S. R. Baier, J. Zempleni, University of Nebraska-Lincoln, personal communication, 2014). Considering that these studies were conducted by using fluorophorelabeled exosomes (7), endogenous vesicles and miRNAs were eliminated as possible confounders. Witwer was not aware of these transport studies at the time of writing his letter.

Second, we fed mice milk miRNA-depleted diets or milk miRNA-sufficient control diets (2). The content of compounds other than miRNAs was identical in both diets [Supplemental Table 2 in (2)]. The plasma miR-29b concentrations were $61 \%$ lower in the deficient group than in sufficient controls. Because the content of nutrients other than miRNAs was identical in both diets, the $61 \%$ decrease in plasma miR-29b can only be explained by an insufficient supply of exogenous, dietary miRNAs.

Third, Witwer points out that Snow et al. did not observe a transfer of dietary miR-21 in miR-21 knockout mice (11). We estimated the dietary supply of miR-21 in the studies by Snow et al. and arrived at the conclusion that, even for the lowest dose of milk used in our studies (a mere $0.25 \mathrm{~L}$ ) (2), the dietary intake (normalized for body weight) of miR-29b exceeded that of miR21 in studies by Snow et al. by $>100$ times. If we decreased the amount of milk in our human feeding studies by a factor of 100 to $2.5 \mathrm{~mL}$, we also would not anticipate observing an increase in miR-29b plasma concentrations [see Fig. 1 and Table 1 in (2)]. However, a dose that low lacks nutritional significance. On a side note, an absence of a postprandial increase in any dietary compound or drug in the peripheral circulation must not be confused with zero bioavailability, because these compounds might have been degraded or stored in the intestinal mucosa or liver in a process referred to as first-pass elimination (12).

Witwer raises some points that we fully endorse. Like him, we believe that the bioavailability of plant miRNAs is negligibly small in humans. We also agree that many unknowns remain to be addressed in the field of dietary miRNAs and are currently working toward creating protocols for distinguishing endogenous and exogenous (milk-borne) miRNAs in human body fluids and tissue samples.

Scott R. Baier Christopher Nguyen Department of Nutrition and Health Sciences University of Nebraska-Lincoln Lincoln, NE

Fang Xie

Jennifer R. Wood Department of Animal Science University of Nebraska-Lincoln Lincoln, NE

\section{Janos Zempleni* \\ Department of Nutrition and Health Sciences University of Nebraska-Lincoln Lincoln, NE}

\section{References}

1. Witwer KW. Diet-responsive mammalian miRNAs are likely endogenous. J Nutr 2014; in press.

2. Baier SR, Nguyen C, Xie F, Wood JR, Zempleni J. MicroRNAs are absorbed in biologically meaningful amounts from nutritionally relevant doses of cow milk and affect gene expression in peripheral blood mononuclear cells, HEK-293 kidney cell cultures, and mouse livers. J Nutr 2014;144.

3. Ross SA, Davis CD. MicroRNA, nutrition, and cancer prevention. Adv Nutr 2011;2:472-85.

4. Hata T, Murakami K, Nakatani H, Yamamoto Y, Matsuda T, Aoki N. Isolation of bovine milk-derived microvesicles carrying mRNAs and microRNAs. Biochem Biophys Res Commun 2010;396:528-33.

5. Gu Y, Li M, Wang T, Liang Y, Zhong Z, Wang X, Zhou Q, Chen L, Lang Q, He Z, et al. Lactation-related microRNA expression profiles of porcine breast milk exosomes. PLoS ONE 2012;7:e43691.

6. Zhou Q, Li M, Wang X, Li Q, Wang T, Zhu Q, Zhou X, Wang X, Gao $\mathrm{X}, \mathrm{Li} \mathrm{X}$. Immune-related microRNAs are abundant in breast milk exosomes. Int J Biol Sci 2012;8:118-23.

7. Tian T, Wang Y, Wang H, Zhu Z, Xiao Z. Visualizing of the cellular uptake and intracellular trafficking of exosomes by live-cell microscopy. J Cell Biochem 2010;111:488-96.

8. Feng D, Zhao WL, Ye YY, Bai XC, Liu RQ, Chang LF, Zhou Q, Sui SF. Cellular internalization of exosomes occurs through phagocytosis. Traffic 2010;11:675-87.

9. Escrevente C, Keller S, Altevogt P, Costa J. Interaction and uptake of exosomes by ovarian cancer cells. BMC Cancer 2011;11:108.

10. Svensson KJ, Christianson HC, Wittrup A, Bourseau-Guilmain E, Lindqvist E, Svensson LM, Morgelin M, Belting M. Exosome uptake depends on ERK1/2-heat shock protein 27 signaling and lipid Raft-mediated endocytosis negatively regulated by caveolin-1. J Biol Chem 2013;288:17713-24.

11. Snow JW, Hale AE, Isaacs SK, Baggish AL, Chan SY. Ineffective delivery of diet-derived microRNAs to recipient animal organisms. RNA Biol 2013;10:1107-16.

12. Pond SM, Tozer TN. First-pass elimination: basic concepts and clinical consequences. Clin Pharmacokinet 1984;9:1-25.

\footnotetext{
${ }^{1}$ Supported by funds provided through the Hatch Act. Additional support was provided by the National Institute of Food and Agriculture (multistate grant W3002) and the NIH (R01 DK063945 and R01 DK077816).

${ }^{2}$ Author disclosures: S. R. Baier, C. Nguyen, F. Xie, J. R. Wood, and J. Zempleni, no conflicts of interest.

* To whom correspondence should be addressed. E-mail: jzempleni2@unl.edu.
} doi:10.3945/jn.114.202606. 